\title{
The Efficacy and Safety of Plerixafor in Hematopoietic Stem Cell Mobilization in Patients with Non-Hodgkin Lymphoma, Multiple Myeloma, and Hodgkin Lymphoma Who Failed Mobilization with Granulocyte-Colony-Stimulating Factor Alone: A Single-Center Experience
}

\begin{abstract}
Introduction: Plerixafor is a CXCR4 antagonist which is administered along with granulocyte-colony-stimulating factor (G-CSF) to mobilize hematopoietic stem cells in patients with Non-Hodgkin lymphoma (NHL) or multiple myeloma (MM), who failed the mobilization with G-CSF alone. Methodology: This was a single-center, retrospective study of the efficacy of the plerixafor and G-CSF in 32 patients with NHL $(n=11)$, MM $(n=11)$, and Hodgkin lymphoma (HL) $(n=10)$ who failed mobilization with G-CSF alone. Results: A median number of $1.21 \times 10^{6}, 1.32 \times 10^{6}$, and $6.73 \times 10^{6} \mathrm{CD} 34+$ cells were mobilized in patients with MM, NHL, and HL, respectively. Overall, $31(96.8 \%)$ patients mobilized more than $2 \times 10^{6} \mathrm{CD} 34+$ stem cells and $21(33.75 \%)$ patients mobilized more than $5 \times 10^{6} \mathrm{CD} 34+$ stem cells. All $32(100 \%)$ patients underwent hematopoietic stem cell transplantation. There were no adverse drug events reported. Conclusion: This retrospective study shows that plerixafor is an effective and safe mobilization agent in patients with NHL, MM, and HL who have failed mobilization with G-CSF alone.
\end{abstract}

Keywords: Hematopoietic stem cell transplantation, multiple myeloma, Non-Hodgkin lymphoma, plerixafor

\section{Introduction}

High-dose chemotherapy combined with autologous hematopoietic stem cell transplantation (auto-HSCT) is the standard of care for patients with relapsed or chemosensitive non-Hodgkin lymphoma (NHL) and multiple myeloma (MM) ${ }^{[1-3]}$

Auto-HSCT improves hematologic recovery in patients by reconstituting hematopoiesis following high-dose chemotherapy. ${ }^{[3]}$ In patients with relapsed or chemosensitive NHL, high-dose chemotherapy with auto-HSCT has been shown to increase disease-free survival, whereas in MM, a combination of high-dose chemotherapy with auto-HSCT improves progression-free survival and overall survival (OS). ${ }^{[4-6]}$ In some situations, auto-HSCT is potentially curative..$^{[7]}$

Employing an effective stem cell mobilization regimen plays a critical role in auto-HSCT. The minimum number of cells

This is an open access journal, and articles are distributed under the terms of the Creative Commons Attribution-NonCommercial-ShareAlike 4.0 License, which allows others to remix, tweak, and build upon the work non-commercially, as long as appropriate credit is given and the new creations are licensed under the identical terms.

For reprints contact: WKHLRPMedknow_reprints@wolterskluwer.com generally acceptable for transplantation

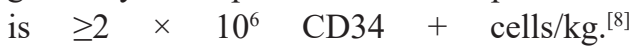
Transplanting fewer than this number of cells may result in delayed engraftment of both platelets and neutrophils. ${ }^{[9]}$ The target number of cells for a single transplant was defined by Weaver et al. ${ }^{[10]}$ as $\geq 5 \times 10^{6}$ $\mathrm{CD} 34+$ cells $/ \mathrm{kg}$, which is important for short-term outcomes, resulting in earlier and more consistent neutrophil, and especially platelet engraftment compared with transplants with lower cell doses. ${ }^{[1]} \mathrm{In}$ some studies, transplant doses of $\geq 5 \times 10^{6}$ CD34 + cells $/ \mathrm{kg}$ have been associated with longer disease-free survival, and OS compared with lower transplant doses. ${ }^{[12,13]}$ Obtaining a sufficient quantity of cells for auto-HSCT is difficult in approximately $20 \%-25 \%$ of patients. ${ }^{[14-16]}$

Until recently, there were two main approaches to stem cell mobilization that involved the use of growth factors, such as granulocyte-colony-stimulating

How to cite this article: Badarkhe $G$, Naik R. The efficacy and safety of plerixafor in hematopoietic stem cell mobilization in patients with Non-Hodgkin lymphoma, multiple myeloma, and Hodgkin lymphoma who failed mobilization with granulocyte-colony-stimulating factor alone: A single-center experience. Indian J Med Paediatr Oncol 2020;41:530-4.
Girish Badarkhe ${ }^{1}$, Radheshyam Naik ${ }^{2}$

${ }^{1} H C G$ Manavata Cancer Centre, Nashik, Maharashtra, India, ${ }^{2} H C G$ Cancer Centre, Bengaluru, Karnataka, India

Submitted: 17-Jul-2019 Revised: 20-Oct-2019 Accepted: 24-Oct-2019 Published: 29-Aug-2020

Address for correspondence: Dr. Radheshyam Naik, HCG Cancer Centre, P. Kalinga Rao Road, Sampangiram Nagar, Bengaluru, Karnataka - 560 020, India. E-mail:Drnaikradheshyam@ gmail.com

Access this article online Website: www.ijmpo.org DOI: 10.4103/ijmpo.ijmpo_154_19 Quick Response Code:

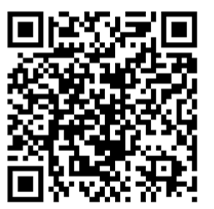


factor (G-CSF) alone (G) or in conjunction with chemotherapy. The administration of chemotherapy before the use of G-CSF produces a higher yield of stem cells for autologous transplantation, but this is not effective for all patients. Around $5 \%-40 \%$ of patients fail to mobilize an adequate number of CD34 + cells with commonly used regimens. ${ }^{[17]}$ These include patients with NHL, elderly patients ${ }^{[18]}$ who are heavily pretreated, ${ }^{[19-21]}$ and patients with MM who previously received multiple cycles of lenalidomide or underwent auto-HSCT. ${ }^{[22]}$ Many patients with Hodgkin lymphoma (HL) who have received extensive cytotoxic chemotherapy previously will turn out to be poor-mobilizers. ${ }^{[23]}$

Advancements in HL therapy have been documented since the introduction of combination chemotherapy protocols and changes in irradiation strategies. Despite these advancements, approximately $10 \%$ of $\mathrm{HL}$ patients remain refractory to these treatments in whom auto-HSCT remains one of the most important alternative treatment modalities. $^{[24]}$

Plerixafor is an additional option for use in auto-HSCT. G-CSF with plerixafor augments the mobilization of CD34 + cells, particularly in patients who are considered poor mobilizers. ${ }^{[25-27]}$

Plerixafor, a bicyclam derivative, is a small molecule which selectively and reversibly antagonizes the CXCR4 chemokine receptor and blocks binding to its cognate ligand, stromal cell-derived factor-1a (SDF-1a). The interruption of the CXCR4/SDF-1a interaction results in mobilization of CD34 + cells to the peripheral blood, where they can be collected for auto-HSCT. ${ }^{[28]}$ The stem cells mobilized by the combination of G-CSF plus plerixafor have been shown to differ from those mobilized by G-CSF alone, with a higher proportion of cells in the growth phase, higher numbers of B- and T-lymphocytes, natural killer cells, dendritic cells, and primitive CD34+ cells. ${ }^{[29-32]}$

\section{Methodology}

This was a retrospective study conducted at HCG Cancer Centre, Bengaluru. The patients' data were retrieved from the medical records from January 2017 to October 2018.

The following data were extracted: baseline characteristics, diagnosis, CD34+ cell counts after plerixafor administration, and adverse events (if any). All patients' data were transcribed onto the case report form maintaining patient anonymity.

The patients included were based on the following inclusion criteria: (1) age 18-78 years; (2) candidates to autologous stem cell transplantation (auto-SCT) for MM, NHL, or HL; (3) who had failed to collect a minimum of $2 \times 10^{6} \mathrm{CD}$ $34+$ cells $/ \mathrm{kg}$ or did not even proceed to apheresis based on a low peripheral blood CD34+ count with mobilization with G-CSF; (4) adequate organ function to undergo apheresis and transplantation; and (5) Eastern Cooperative Oncology Group Performance Status 0-2.

Exclusion criteria included: (1) diagnosis of any form of acute or chronic leukemia (including plasma cell leukemia) or myelodysplastic syndrome; (2) comorbid conditions which render the patient at high risk from treatment complications; (3) vasculitis or autoimmune disorders; (4) brain metastases, carcinomatous meningitis, or any other malignancy unless the patient had been disease-free for at least 5 years after curative intent therapy; and (5) clinically significant heart disease.

Each patient's mobilization regimen was determined by the bone marrow transplant physician. Patients received G-CSF as per the standard protocol, typically as a $10 \mathrm{mg} / \mathrm{kg}$ daily s.c. injection each morning for 4 consecutive days. From the evening of the $4^{\text {th }}$ day, patients received a single injection of s.c. plerixafor at the dose of $0.24 \mathrm{mg} / \mathrm{kg}$, administered at least $11 \mathrm{~h}$ prior to the following day's apheresis schedule. On the morning of the $5^{\text {th }}$ day, G-CSF was administered, and apheresis began at approximately $10-12 \mathrm{~h}$ after plerixafor and at $1 \mathrm{~h}$ after G-CSF administration. The administration of plerixafor + G-CSF and apheresis was repeated daily until the collection target was achieved (sufficient cells for auto-SCT [minimum $2 \times 10^{6} / \mathrm{kg}$ ]) or up to a maximum of four doses of plerixafor was given in total or the patient had failed to mobilize enough peripheral blood stem cells to warrant continuation. The number of $\mathrm{CD} 34+$ cells collected during each apheresis session was recorded. Descriptive statistics were used to analyze the data.

\section{Results}

The study included a total of 32 consecutive patients in whom the mobilization was performed using G-CSF plus plerixafor following previous mobilization failure with G-CSF alone. Patients were heavily pretreated and received a median of two lines of different chemotherapy regimen before mobilization with G-CSF plus plerixafor. The demographic, clinical characteristics, and mobilization data are summarized in Table 1.

Table 1: Demographic/clinical characteristics of the study cohort $(n=32)$

\begin{tabular}{lc}
\hline & $\boldsymbol{n} \mathbf{( \% )}$ \\
\hline Number of patients & 32 \\
Age (years), median (range) & $41.4(21-63)$ \\
Gender & $20(45.45)$ \\
Male & $12(54.54)$ \\
Female & \\
Primary diagnosis & 11 \\
NHL & 11 \\
MM & 10 \\
HL & 2 \\
Prior lines of chemotherapy, average & \\
\hline MM - Multiple myeloma; HL - Hodgkin lymphoma; NHL - Non- \\
Hodgkin lymphoma
\end{tabular}


Table 2: Mobilization features

\begin{tabular}{|c|c|c|c|}
\hline Mobilization features & $\operatorname{MM}(n=11)$ & NHL $(n=11)$ & HL $(n=10)$ \\
\hline Cumulative $\mathrm{CD} 34+$ cells $/ \mathrm{kg} \times 10^{6}$ collected & 10.21 & 7.32 & 6.73 \\
\hline Median number of patients collecting minimal cell dose $\left(\geq 2 \times 10^{6} \mathrm{CD} 34+\right.$ cells $\left./ \mathrm{kg}\right)(\%)$ & $11(100)$ & $10(90.90)$ & $10(100)$ \\
\hline Days to collect minimal cell dose, median & 1.5 & 2 & 2.4 \\
\hline $\begin{array}{l}\text { Number of patients collecting optimal cell dose }\left(\geq 5 \times 10^{6} \text { in NHL and } \geq^{6} \times 106 \text { in MM CD34+ cells } / \mathrm{kg}\right) \\
(\%)\end{array}$ & $8(72.72)$ & $6(54.54)$ & $7(70)$ \\
\hline Days to collect optimal cell dose, median & 2.5 & 2.8 & 2.8 \\
\hline
\end{tabular}

MM - Multiple myeloma; HL - Hodgkin lymphoma; NHL - Non-Hodgkin lymphoma

\section{Mobilization}

In $31(96.8 \%)$ patients, a minimum threshold for peripheral stem cells, defined as $2 \times 10^{6} \mathrm{CD} 34+$ stem cells, was collected following G-CSF + plerixafor mobilization procedure. A median of 1.5 and 2 days was required to mobilize $2 \times 10^{6} \mathrm{CD} 34+$ stem cells in MM and NHL, respectively.

In $8(72.72 \%)$ patients with $\mathrm{MM}$, an optimal threshold for peripheral stem cells, defined as $6 \times 10^{6} \mathrm{CD} 34+$ stem cells, was collected following G-P mobilization procedure, requiring a median of 2.5 days for mobilization.

In $6(54.54 \%)$ patients with NHL, an optimal threshold for peripheral stem cells, defined as $5 \times 10^{6} \mathrm{CD} 34+$ stem cells, was collected following $\mathrm{G}-\mathrm{P}$ mobilization procedure, requiring a median of 2 days for mobilization. Table 2 depicts the mobilization features of the patients.

No major adverse events were observed during this study.

\section{Discussion}

Our data confirm that plerixafor in combination with G-CSF is an effective alternative measure for poor mobilizers with G-CSF alone in NHL, HL, and MM patients. Plerixafor was well tolerated by our patients which is in accordance with other studies reporting only mild side effects associated with plerixafor. ${ }^{[33]}$

The mobilization efficacy of plerixafor has been demonstrated in combination with G-CSF for primary mobilization in adult patients with MM or NHL in two Phase III, multicenter, randomized, placebo-controlled trials. ${ }^{[34,35]}$ Fifty-nine percent of adults with NHL were able to achieve the primary endpoint collection of $5 \times 10^{6}$ CD34 cells $/ \mathrm{kg}$, and $87 \%$ of them were able to reach the secondary endpoint collection of $2 \times 10^{6} \mathrm{CD} 34$ cells $/ \mathrm{kg}$. Target stem cell collection of $\geq 5 \times 10^{6} \mathrm{CD} 34+$ cells $/ \mathrm{kg}$ was achieved within 4 apheresis days in the plerixafor plus G-CSF group. ${ }^{[34]}$

In the MM trial, the primary collection endpoint of $6 \times 10^{6}$ CD34 cells $/ \mathrm{kg}$ was met by $72 \%$ of participants versus $34 \%$ in placebo group, and $95 \%$ of them were able to reach the secondary endpoint collection of $2 \times 10^{6}$ CD34 cells $/ \mathrm{kg}$. Target stem cell collection of $\geq 6 \times 10^{6} \mathrm{CD} 34+$ cells $/ \mathrm{kg}$ was achieved within 2 apheresis days in the plerixafor plus G-CSF group. ${ }^{[35]}$ In both studies, patients tolerated plerixafor, and for patients who underwent auto-HSCT, their hematopoietic recovery process and engraftment status were unremarkable. In both studies, auto-HSCT after mobilization with plerixafor and placebo resulted in successful engraftment of neutrophils and platelets. The durability of grafts was similar for plerixafor and placebo through 12 months of follow-up. Both regimens were associated with similar survival rates at 12 months posttransplantation. ${ }^{[34,35]}$

Our experiences showed that most patients with HL with poor mobilization following G-CSF alone showed favorable responses to the addition of plerixafor, which might have averted costly and time-consuming remobilization attempts and contributed to the successful mobilization of CD34+ cells.

Several pharmacoeconomic studies have shown that plerixafor, when given to poor mobilizers, decreased mobilization failure rates at an acceptable increase in costs for patients with MM and NHL.

Our study is limited by its retrospective nature and relatively small patient population size. Despite these limitations, our data have shown that plerixafor is an effective and safe mobilization agent in patients with NHL and MM who have failed mobilization with G-CSF alone.

\section{Conclusion}

Plerixafor is indicated along with Granulocyte-Colony Stimulating Factor (G-CSF) to mobilize hematopoietic stem cells in patients with NHL or MM, who failed the mobilization with G-CSF alone. This single-centre retrospective study reiterates that plerixafor is an effective and safe mobilization agent in patients with NHL, MM, and HL who have failed mobilization with G-CSF alone.

Financial support and sponsorship

Nil.

\section{Conflicts of interest}

There are no conflicts of interest.

\section{References}

1. Bensinger W, DiPersio JF, McCarty JM. Improving stem cell mobilization strategies: Future directions. Bone Marrow Transplant 2009;43:181-95. 
2. Flomenberg N, DiPersio J, Calandra G. Role of CXCR4 chemokine receptor blockade using AMD3100 for mobilization of autologous hematopoietic progenitor cells. Acta Haematol 2005;114:198-205.

3. Josefsen D, Rechnitzer C, Parto K, Kvalheim G. The use of plerixafor for peripheral blood stem cell mobilisation reduces the frequency of mobilisation failure in patients planned to undergo autologous transplantation. Eur Haematol 2010;4:24-9.

4. Sehn LH, Fenske TS, Laport GG. Follicular lymphoma: Prognostic factors, conventional therapies, and hematopoietic cell transplantation. Biol Blood Marrow Transplant 2012;18:S82-91.

5. Child JA, Morgan GJ, Davies FE, Owen RG, Bell SE, Hawkins $\mathrm{K}$, et al. High-dose chemotherapy with hematopoietic stem-cell rescue for multiple myeloma. $N$ Engl $\mathrm{J}$ Med 2003;348:1875-83.

6. Wach M, Cioch M, Hus M, Jawniak D, Legiec W, Malek M, et al. Treatment of multiple myeloma patients with autologous stem cell transplantation - A fresh analysis. Folia Histochem Cytobiol 2011;49:248-54.

7. Kouroukis CT, Varela NP, Bredeson C, Kuruvilla J, Xenocostas A. Plerixafor for autologous stem-cell mobilization and transplantation for patients in Ontario. Curr Oncol 2016;23:e409-30.

8. Jillella AP, Ustun C. What is the optimum number of CD34+peripheral blood stem cells for an autologous transplant? Stem Cells Dev 2004;13:598-606.

9. Stockerl-Goldstein KE, Reddy SA, Horning SF, Blume KG, Chao NF, Hu WW, et al. Favorable treatment outcome in non-Hodgkin's lymphoma patients with "poor" mobilization of peripheral blood progenitor cells. Biol Blood Marrow Transplant 2000;6:506-12.

10. Weaver $\mathrm{CH}$, Hazelton $\mathrm{B}$, Birch $\mathrm{R}$, Palmer P, Allen C, Schwartzberg L, et al. An analysis of engraftment kinetics as a function of the CD34 content of peripheral blood progenitor cell collections in 692 patients after the administration of myeloablative chemotherapy. Blood 1995;86:3961-9.

11. Shpall EJ, Champlin R, Glaspy JA. Effect of CD34+ peripheral blood progenitor cell dose on hematopoietic recovery. Biol Blood Marrow Transplant 1998;4:84-92.

12. Blystad AK, Delabie J, Kvaløy S, Holte H, Vålerhaugen H, Ikonomou I, et al. Infused CD34 cell dose, but not tumour cell content of peripheral blood progenitor cell grafts, predicts clinical outcome in patients with diffuse large B-cell lymphoma and follicular lymphoma grade 3 treated with high-dose therapy. Br J Haematol 2004;125:605-12.

13. Bolwell BJ, Pohlman B, Rybicki L, Sobecks R, Dean R, Curtis J, et al. Patients mobilizing large numbers of CD34+cells ("super mobilizers") have improved survival in autologous stem cell transplantation for lymphoid malignancies. Bone Marrow Transplant 2007;40:437-41.

14. Boeve S, Strupeck J, Creech S, Stiff PJ. Analysis of remobilization success in patients undergoing autologous stem cell transplants who fail an initial mobilization: Risk factors, cytokine use and cost. Bone Marrow Transplant 2004;33:997-1003.

15. Nademanee AP, DiPersio JF, Maziarz RT, Stadtmauer EA, Micallef IN, Stiff PJ, et al. Plerixafor plus granulocyte colony-stimulating factor versus placebo plus granulocyte colony-stimulating factor for mobilization of CD34(+) hematopoietic stem cells in patients with multiple myeloma and low peripheral blood CD34(+) cell count: Results of a subset analysis of a randomized trial. Biol Blood Marrow Transplant 2012;18:1564-72.

16. Maziarz RT, Nademanee AP, Micallef IN, Stiff PJ, Calandra G, Angell $\mathrm{J}$, et al. Plerixafor plus granulocyte colony-stimulating factor improves the mobilization of hematopoietic stem cells in patients with non-Hodgkin lymphoma and low circulating peripheral blood CD34+cells. Biol Blood Marrow Transplant 2013;19:670-5.

17. Jantunen E, Lemoli RM. Preemptive use of plerixafor in difficult-to-mobilize patients: An emerging concept. Transfusion 2012;52:906-14.

18. Lysák D, Kořístek Z, Gašová Z, Skoumalová I, Jindra P. Efficacy and safety of peripheral blood stem cell collection in elderly donors; does age interfere? J Clin Apher 2011;26:9-16.

19. Kumar S, Dispenzieri A, Lacy MQ, Hayman SR, Buadi FK, Gastineau DA, et al. Impact of lenalidomide therapy on stem cell mobilization and engraftment post-peripheral blood stem cell transplantation in patients with newly diagnosed myeloma. Leukemia 2007;21:2035-42.

20. Mazumder A, Kaufman J, Niesvizky R, Lonial S, Vesole D, Jagannath S. Effect of lenalidomide therapy on untreated multiple myeloma patients. Leukemia mobilization of peripheral blood stem cells in previously 2008;22:1280-1.

21. Basak GW, Jaksic O, Koristek Z, Mikala G, Basic-Kinda S, Mayer $\mathrm{J}$, et al. Haematopoietic stem cell mobilization with plerixafor and G-CSF in patients with multiple myeloma transplanted with autologous stem cells. Eur J Haematol 2011;86:488-95.

22. Giralt S, Costa L, Schriber J, Dipersio J, Maziarz R, McCarty $\mathrm{J}$, et al. Optimizing autologous stem cell mobilization strategies to improve patient outcomes: Consensus guidelines and recommendations. Biol Blood Marrow Transplant 2014;20:295-308

23. Canales MA, Fernández-Jiménez MC, Martín A, Arrieta R, Caballero MD, Díez J, et al. Identification of factors associated with poor peripheral blood progenitor cell mobilization in Hodgkin's disease. Haematologica 2001;86:494-8.

24. Duarte FB, Fernandes MG, Kaufmann J, Barroso KS, Leitão JP, Araujo BS, et al. Hodgkin's lymphoma evaluation of patients submitted to autologous transplantation of hematopoietic cells in the hematology service of the hospital Walter Cantídio - Fortaleza, Brazil. Rev Assoc Med Bras (1992) 2016;62 Suppl 1:34-8.

25. D'Addio A, Curti A, Worel N, Douglas K, Motta MR, Rizzi S, et al. The addition of plerixafor is safe and allows adequate PBSC collection in multiple myeloma and lymphoma patients poor mobilizers after chemotherapy and G-CSF. Bone Marrow Transplant 2011;46:356-63.

26. Danylesko I, Sareli R, Varda-Bloom N, Yerushalmi R, Shem-Tov N, Shimoni A, et al. Plerixafor (Mozobil): A stem cell-mobilizing agent for transplantation in lymphoma patients predicted to be poor mobilizers - A pilot study. Acta Haematol 2016;135:29-36.

27. Gazitt Y, Freytes CO, Akay C, Badel K, Calandra G. Improved mobilization of peripheral blood CD34+ cells and dendritic cells by AMD3100 plus granulocyte-colony-stimulating factor in non-Hodgkin's lymphoma patients. Stem Cells Dev 2007; 16:657-66.

28. Duarte RF, Shaw BE, Marín P, Kottaridis P, Ortiz M, Morante C, et al. Plerixafor plus granulocyte CSF can mobilize hematopoietic stem cells from multiple myeloma and lymphoma patients failing previous mobilization attempts: EU compassionate use data. Bone Marrow Transplant 2011;46:52-8.

29. Varmavuo V, Mäntymaa $P$, Kuittinen $T$, Nousiainen $T$, Jantunen E. Blood graft lymphocyte subsets after plerixafor injection in non-Hodgkin's lymphoma patients mobilizing poorly with chemotherapy plus granulocyte-colony-stimulating factor. Transfusion 2012;52:1785-91. 
30. Devine SM, Vij R, Rettig M, Todt L, McGlauchlen K, Fisher N, et al. Rapid mobilization of functional donor hematopoietic cells without G-CSF using AMD3100, an antagonist of the CXCR4/ SDF-1 interaction. Blood 2008;112:990-8.

31. Fruehauf S, Veldwijk MR, Seeger T, Schubert M, Laufs S, Topaly J, et al. A combination of granulocyte-colony-stimulating factor (G-CSF) and plerixafor mobilizes more primitive peripheral blood progenitor cells than G-CSF alone: Results of a European phase II study. Cytotherapy 2009;11:992-1001.

32. Larochelle A, Krouse A, Metzger M, Orlic D, Donahue RE, Fricker S, et al. AMD3100 mobilizes hematopoietic stem cells with long-term repopulating capacity in nonhuman primates. Blood 2006; 107:3772-8.

33. Russell N, Douglas K, Ho AD, Mohty M, Carlson K, Ossenkoppele GJ, et al. Plerixafor and granulocyte colony-stimulating factor for first-line steady-state autologous peripheral blood stem cell mobilization in lymphoma and multiple myeloma: Results of the prospective PREDICT trial. Haematologica 2013;98:172-8.

34. DiPersio JF, Micallef IN, Stiff PJ, Bolwell BJ, Maziarz RT, Jacobsen E, et al. Phase III prospective randomized double-blind placebo-controlled trial of plerixafor plus granulocyte colony-stimulating factor compared with placebo plus granulocyte colony-stimulating factor for autologous stem-cell mobilization and transplantation for patients with non-Hodgkin's lymphoma. J Clin Oncol 2009;27:4767-73.

35. DiPersio JF, Stadtmauer EA, Nademanee A, Micallef IN, Stiff PJ, Kaufman JL, et al. Plerixafor and G-CSF versus placebo and G-CSF to mobilize hematopoietic stem cells for autologous stem cell transplantation in patients with multiple myeloma. Blood 2009;113:5720-6. 